\title{
The twentieth century science paradoxes
}

\author{
Victoria Kondratenko \\ V.M.Glushkov Institute of Cybernetics of NAS of Ukraine \\ Glushkov Avenue 40, Kyiv, Ukraine, 03187 \\ science.and.life@gmail.com, orcid.org/0000-0003-1577-6701 \\ Received on 03.12.2019, accepted after revision on 03.07.2020 \\ https://doi.org/10.32347/tit2021.42.0303
}

\begin{abstract}
The isolation of hypothetical theories from the realities of living matter has caused mysticism to penetrate scientific theories. With mystical thinking, the idea of using an analytical method to solve cognitive problems does not occur. Dialectical logic, in contrast to mysticism, states the opposite: any problematic tasks of cognizing the vital processes and phenomena of the universe are solvable exclusively in an analytic way, with the only method. The author created a universal and formal theory of solving intellectual (i.e., having no previously known algorithms for solving) problems associated with the knowledge of the vital functions of natural and man-made processes in any phenomena of the universe - the Kondratenko method of axiomatic modeling, the effectiveness of which is achieved by correctly setting the problem and solving it purely formal method. The correctness of the statement of the problem means, first of all, the recognition of the failure of all hypothetical (not confirmed by the results of full-scale experimentation with the subject of knowledge) theories. This requirement, in particular, to the mathematical tools used to solve problems of cognition, it revealed paradoxes in the foundations of mathematics, which are discussed in the article.

At present, in the natural and applied sciences in most publications, i.e. more than $90 \%$ associated with the construction of formal theories in these sciences, the proof of theorems is carried out: first$l y$, in a meaningful way, which contradicts the urgent requirement of philosophers of science to use exclusively formal evidence, which is a criterion for assessing the correctness and reliability of evidence; secondly, in substantive evidence in $95 \%$ of cases, an exclusively standard list of tautologies is used, which by definition is incorrect for the purpose of proving theorems on phenomena and pro-
\end{abstract}

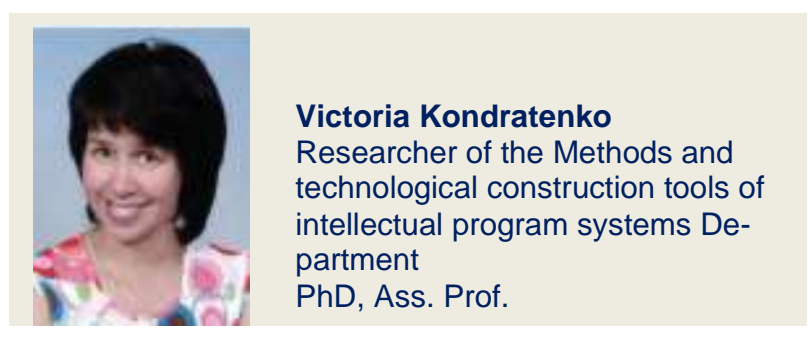

cesses of the universe based on exclusively true axioms obtained as a result of full-scale experimentation with these phenomena and processes. The article deals with the paradox in the classical approach to proving theorems, which consists in the inappropriateness of generally accepted stereotypical tautologies of classical mathematics for proving theorems.

Keywords: axiomatic modeling, artificial intelligence, mathematical logic, thinking, formalization.

\section{INTRODUCTION}

In the last decade, interest in the sciences studying the human brain has grown tremendously. Publications on neurobiology today have quantitatively surpassed publications on physics and mathematics. Since ancient Egypt, people were eager to look into the human brain, but today the growing interest in the processes of human thinking, I think, is dictated by harsh necessity. The demand for this kind of knowledge is dictated not so much by the rapid development of world science as by "dead ends" and stagnation in the previous scientific century. The need for states econom- 
ic growth in times of crisis, their fierce competition in the international arena for leadership and the disharmony of the development of modern civilization are forcing to seek new ways for the intensive development of society. There are no such proposals from science today. There is a fair hope that having understood the processes of human thinking, science will indicate the right path for further scientific and civilizational development. However, success requires more than just finding new ways. In my opinion, competently conducted "work on mistakes" of the previous period of science development is no less effective. And I propose starting this work from the basics: from the foundations of mathematics, rightfully called the queen of all sciences [1 - 5], which will serve the purpose of this article.

Man, by definition, is a "homo sapiens", since his genome contains a complex of inherited genes that implement biological tools of rational activity (BTRA) $[6,7]$. The BTRA is capable of not only operating with the socalled signaling information, but also performing a complex of computational operations on it, dictated by the full human body functioning [8 - 11]. Intelligence assets are accumulated throughout a person's life in the process of learning knowledge, skills and abilities. Assets are stored in the knowledge base attached to the BTRA. The base itself consists of two sections. In the first section, realistic knowledge is stored, used exclusively to control the real life of a person. The second section contains abstract knowledge used exclusively for abstract rational activity. For example, dreams, fantasies. BTRA requires a high-speed associative search engine serving both of the above knowledge base sections. Knowledge of the BTRA architecture gives us reason to be guided by the requirement to use exceptionally realistic knowledge in solving problematic tasks related to predicting the evolution of the vital processes of real processes in the universe. However, it is known that there are forecasting technologies based on hypothetical theories. The concept "hypothetical" means in this context $100 \%$ isolation from field experimentation. The isolation of hypothetical theories from the realities of living matter has caused mysticism to penetrate scientific theories. This will be discussed not only in this article, but in subsequent ones, as well as in my previous articles on this topic. Unfortunately, there are many examples of this. A reasonable explanation of the situation in science in general, and in mathematics in particular, is impossible to find, since biological sciences, coupled with cognitive science, have practically learned the secrets of human rational thinking, based on field experimentation and rejecting hypothetical theories in principle, as theories that contradict human BTRA capabilities [12 - 15]. Any mathematical statement, if it is not a postulate, must be proved. It is proved in a formal way, i.e. without the subjective influence of a person on the result of evidence.

Relevance of the topic. At present, in the natural and applied sciences in most publications, i.e. more than $90 \%$ associated with the construction of formal theories in these sciences, the proof of theorems is carried out:

- firstly, in a meaningful way, which contradicts the urgent requirement of philosophers of science to use exclusively formal evidence, which is a criterion for assessing the correctness and reliability of evidence;

- secondly, in substantive evidence in $95 \%$ of cases, an exclusively standard list of tautologies is used, which by definition is incorrect for the purpose of proving theorems on phenomena and processes of the universe based on exclusively true axioms obtained as a result of full-scale experimentation with these phenomena and processes.

The task formulation. The article analyzes commonly used standard list of tautologies:

- modus ponens: $\mathrm{A} \wedge(\mathrm{A} \Rightarrow \mathrm{B}) \Rightarrow \mathrm{B}$

- modus tollens: $\left((\mathrm{A}=>\mathrm{B}) \Lambda^{\prime} \mathrm{IB}\right)=>^{\prime} \mathrm{IA}$

- syllogism:

- $((\mathrm{A}=>\mathrm{B}) \Lambda(\mathrm{B}=>\mathrm{C}))=>(\mathrm{A}=>\mathrm{C})$

- counter position: $(A=>B)=>$

$$
\Rightarrow(\text { IB }=>\text { 'IA })
$$

\section{METHOD FOR SOLVING THE PROBLEM}

Proof of the unsuitability of the modus ponens rule for proving theorems. 
Modus ponens formula rules, see (1):

$$
\mathrm{A} \wedge(\mathrm{A} \Rightarrow \mathrm{B}) \Rightarrow \mathrm{B}
$$

in classical mathematics, it is invariant to the initial truth values of the component subformulas A and B. And even more invariant, to the $\mathrm{A}$ and $\mathrm{B}$ subformulas components, if these subformulas are composite. The modus ponens rule itself does not declare the elementary nature of the A and B subformulas.

However, in real life, researchers have to work when formulating and proving theorems on the phenomena of the universe exclusively with axioms (facts of full-scale experimentation with these phenomena), which in the foundations of mathematics received two alternative names:

- elementary logical formulas

- single letter disjoints.

And so, when the modus ponens formula: $\mathrm{A} \wedge(\mathrm{A} \Rightarrow \mathrm{B}) \Rightarrow \mathrm{B}$ (1) is being alone only with single letter clauses, it not only does not indicate a bright way to obtain the conclusion of the truth of the premises in a purely theoretical way, but it also poses the problem solver that, in proving the theorems, the truth of both logical variable $A$ and logical variable $B$, so that there is no conflict with the predicate logic semantics of the language, functionally fully represented in the following Table 1:

\section{Table 1}

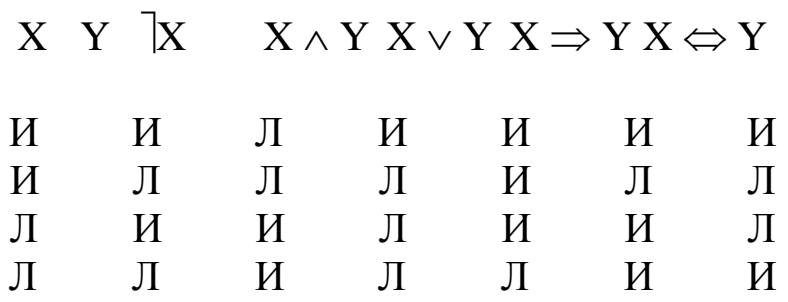

Indeed, in this case, the first line shows that the formula (1) receives the true value for all true premises and the true conclusion of the theorem.

However, the semantics of the language of first-order predicate logic indicates that formula (1) can also get true value for truth values of single letter clauses corresponding to lines 3 and 4 of the language semantics Table 1. This corresponds to the complete absurdity in the proof of the theorems, since false single letter disjunctions reflecting the meaning of specific real axioms obtained in the course of field experimentation are unacceptable in the premises of the theorems. In the case of the modus rule, the theorem should be considered incorrectly formulated. But formulating correctly any theorem within the framework of the modus rule definition of freedom degrees is fundamentally impossible.

Thus, another insoluble paradox is generated in the beginnings of mathematics. True, there is only one correct way out of this paradox, but it will bury the modus ponens rule itself forever. The way out is to limit the number of degrees of freedom when defining operands in a modus ponens rule. As the operands of this rule, exclusively true axioms should be used, functionally fully characterizing all the admissible states of the observed phenomenon in the universe, and obtained only in the process of full-scale experimentation with this phenomenon. Moreover, this requirement should equally apply both to axioms acting as premises in the theorem, and to axioms acting as conclusions in the theorem. But even with such a limitation that allows us to correctly formulate the theorem, it is still impossible to obtain a proof of the theorem conclusion truth from the truth of the conjunction of its premises in a purely theoretical formal way [3]. For the reasons related to incomplete cognition by the international scientific community of the human psyche, which (cognition), according to optimistic estimates, can be completed no earlier than in 500 years.

The complete knowledge of the human psyche will reveal the secret of nature, in particular, about living matter, concerning (the secret) of a rigid relationship at the molecular level between two components [4]:

1) information on this matter, on the one hand, from which the higher mental functions of the central nervous system of a person are operated (including mathematical and graphic operations), including consciousness, thinking, imagination, perception, memory and scientific creativity;

2) investigated biological matter on the other hand, involved in this operation. 
The disclosure of the mentioned secret will leave no room for use in theories of false hypothetical axioms, since any of the axioms will have material evidence of its truth or falsehood.

The requirement to disclose the mentioned mystery additionally follows from the postulates given below in order to confirm their truth, since they (postulates) are the keys in molecular biology and normal physiology and determine the basic foundation for the existence of a biological form of matter:

$\checkmark$ the postulate of the trinity of bioorganic matter, chemical energy and molecular information of living matter, declaring not only the nature of heredity, but also in general, the nature of all the rational activity of individuals, together with their reflex activity in the process of knowing the environment of existence; $\checkmark$ the postulate of interdependence between the main components of living matter: information, structure, energy and function in various biological processes;

$\checkmark$ a postulate stating that for living forms of matter, reflection is a condition for ensuring the unity of the organism and the external environment, without which the existence of a living form is impossible;

$\checkmark$ a postulate stating that information, just like chemical energy, reveals complete affinity for living matter at its elementary level. Indeed, all biochemical elements of biological molecules represent that elementary form of organic matter, with the help of which biological codes of molecular information are formed and transmitted;

$\checkmark$ a postulate stating that information, in a philosophical sense, is neither matter nor energy - it is only a property of matter.

In molecular biology, information acquires its physical embodiment and meaning already at the level of molecular units of biological information (letters or symbols) that are used in a living cell to encode and program biological molecules. It follows that information in molecular biology is not an abstract concept, but an objective property and, moreover, the very content and essence of living matter. Biological molecules and structures, as carriers of the just mentioned types of information, are constantly in informational interaction with each other and the control center of the individual psyche. Therefore, all of them may well be recognized as informational "entities".

Thus, only a rigid relationship at the molecular level between information subject to operation and the biological matter involved in this operation allows the correct formal proof of theorems in the process of scientific knowledge of this matter.

A similar approach to information, in which it (information) is identified as an objective property of each specific matter, bearing the burden of the content and essence of matter and transforming at the molecular level into matter itself, should also be developed in the process of cognition of inanimate matter.

As we have just seen, the modus ponens rule does not provide the possibility of obtaining a purely theoretical formal way of proving the truth of the conclusion of a theorem from the truth of the conjunction of its premises. Therefore, at present, the truth of all axioms, both in premises and in the conclusions of theorems, has to be determined solely by field experimentation.

It would seem that in such a situation, a formal proof of the theorems should be reasonably abandoned. But this is permissible only if one neglects the control of the logical thinking correctness of the problem solver in the case of his reasoning with a logical consequence in the structure of the "premiseconclusion" statement. This correctness is checked exclusively by the formal derivability of the conclusion truth from the conjunction of premises truth, based on the syntax and semantics of the formal language of this formal theory. That is why philosophers of science require precisely the formal proof of theorems in all formal theories [16-19].

\section{CONCLUSION}

The modern proof is carried out on the standard stereotype of the generalized logical formula (3) created by the author [3] of any theorem, which is represented by writing the entire theorem with abstract logical variables as the premise (left side) of the generalized 
theorem, and recording one or more interpretations of this theorem (obtained in the field experiment) as a conclusion to a generalized theorem.

The formal derivability of any interpretation of this formula from an abstract formula establishes two facts [20-22]:

- the fact of correct thinking in the formulation and solution of a specific task problem;

- the fact of an objective and correct proof of the truth of the formulated theorem.

Similar considerations indicate the unsuitability of the modus tollens rule, see (2):

$$
\left((\mathrm{A}=>\mathrm{B}) \Lambda^{\prime} \mathrm{IB}\right)=>^{\prime} \mathrm{IA} \text {, }
$$

to prove the theorems, since the formula (2) can get the true value eve - for truth values of one-liter clauses corresponding to lines 1, 2 and 4 of the language semantics Table 1, which corresponds to the complete absurdity in proving the theorems.

Similar considerations indicate the unsuitability of the syllogism rule, see (3):

$$
((\mathrm{A}=>\mathrm{B}) \Lambda(\mathrm{B}=>\mathrm{C}))=>(\mathrm{A}=>\mathrm{C}),
$$

to prove the theorems, since the formula (3) can get the true value even for truth values of single letter clauses corresponding to lines 1 4 of the language semantics table, which corresponds to the complete absurdity in proving the theorems.

Similar considerations indicate the inappropriateness of the counterposition rule, see (4):

$$
(\mathrm{A}=>\mathrm{B})=>\left({ }^{\prime} \mathrm{IB}=>^{\prime} \mathrm{IA}\right)
$$

to prove the theorems, since the formula (4) can get the true value even for the truth values of single letter clauses corresponding to lines $1-4$ of the language semantics Table 1 , which corresponds to the complete absurdity in proving the theorems.

\section{REFERENCES}

1. Kondratenko V.A., 2015. Paradoxes of science of the twentieth century. The twenty first century - dialectic logic against mysticism, Kyiv, Scientific publication Zadruga, 200 (in Rus- sian).

2. Kondratenko V.A., 2014. A living matter in an image of formal models (From physiological heredity to intelligence with its assets). The collection of articles of the author, Kyiv, Scientific publication of LLC, Yunik Print, 186 (in Russian).

3. Kondratenko V.A., 2010. Creation of a uniform stereotype of a logical design of thinking for the substantial and formal proof of theorems. Kyiv Scientific publication of Alephof, 267 (in Russian).

4. Kondratenko V.A., 2017. Artificial intelligence. A plan and realities of the current time against the background of natural intelligence of the person. Kyiv, Scientific publication Zadruga, 84 (in Russian).

5. Lyalkina G.B., 2012. Mathematical foundations of decision theory. Ed. V.A.Trefilova. Guidance. Perm, Perm Publishing House. Polytechnic University, 118 (in Russian).

6. Anokhin P.K., 1998. Chosen works. Cybernetics of functional systems. Moscow, Medicine, 400 (in Russian).

7. Agadzhanyan N.A. Tel L.Z., Tsirkin V.I., Chesnokova S.A., 2003. Human physiology. (The textbook for medical higher education institutions), under the editorship of the academician of the Russian Academy of Medical Science Agadzhanyan and professor N.A. Tsirkin, the Medical book, N. Novgorod, NGMA Publishing house, 408 (in Russian).

8. Petro Kulikov, Mykhailo Sukach, 2015. About readiness of Ukraine to mastering minerals of world ocean. Underwater Technologies, Iss.02, 3-10 (in Russian).

9. Nikolay Zhuk, Myron Nazarian, Yury Stelmakhov, 2015. Great Silk Road: modern problems of reconstruction. Underwater Technologies, Iss.01, 59-64 (in Russian).

10.Andrey Tevyashev, 2018. Information and analytical technology for optimal management of sustainable development and functioning of water supply systems. New horizon of underwater explorations. Underwater Technologies, Iss.08, 47-49 (in Russian).

11.Kobylyanu G.N., Grischenkov E.N., Kuznetsov V.I., Mansur T.I., 2017. Emergency cardiological care in general medical practice: a training manual. RUDN, 77 (in Russian).

12. Kondratenko V.A., 2016. Dialectic logic of management of the autonomic nervous system of the person. Computer mathematic, No.1, 125-133 (in Russian).

13.Kondratenko VA, 2011. Quantum physics 
without the geometrization of physical models of the universe, a priori free of hypothetical and incorrect formalisms. Kyiv: Scientific publication "Aleph", 107 (in Russian).

14.Castells M., 2004. Information Technologies, Globalization and Social Development. Kyiv, Ekonomika znan: vукlуку globalizacii i Ukraina, 83-87 (in Ukrainian).

15.Maksimov V.I., Kornoushenko E.K., Kachaev S.V., 1999. Cognitive technologies to support management decision making. Moscow, Informacionnoe obshchestvo, No.2, 50-57 (in Russian).

16.Li Endryu, 2016. Information - Overcoming Uncertainty. M., Sb.: Teorii vsego na svete. Pod red. Dzhona Brokmana, «Binom»; Laboratoriya znaniy, 162-163 (in Russian).

17.Luger J.F., 2003. Artificial Intelligence: Strategies and Methods for Solving Complex Problems. 4nd ed. In Russian translated from english. Moscow, Vil'yams, 864.

18.McLuhan Marshall, 1964. Understanding media: the extensions of man. New York, McGraw-Hill, 359.

19.Newell A., Simon H. A., 1972. Human problem solving. New York, Englewood Cliffs, Prentice-Hall, 154.

20.Okinawan Charter for a Global Information Society, 2000. Moscow, Informacionnoe obshchestvo, No.4, 53-57 (in Russian).

21.Preston D., 2014. Some Ontology of Interactive Art. Philosophe and Technology, Vol.27, No.2, 267-278.

22.Sukach M., 2015. First international scientifically-practical conference Underwater technologies, 2015. Kyiv, Underwater Technologies, Vol.01, 3-12 (in Ukrainian).

23.Turing A.M., 1950. Computing Machinery and Intelligence. Source: Mind, New Series, Vol.59, No.236 (Oct.), 433-460.

24.Zenkin A.A., 1996. Knowledge-generating technologies of cognitive reality. Moscow, Novosti Iskustvennogo Intellekta, No.2, 72-78 (in Russian).

\section{Парадоксы науки двадцатого века}

\section{Виктория Кондратенко}

Аннотация. Оторванность гипотетических теорий от реалий живой материи стала причиной проникновения мистики в научные теории. При мистическом мышлении идея применения аналитического метода решения задач познания в голову не приходит. Диалектическая логика в отличие от мистики утверждает обратное: любые проблемные задачи познания жизнедеятельности процессов и явлений мироздания разрешимы исключительно аналитическим путём, при этом единственным методом. Автором создана универсальная и формальная теория решения интеллектуальных (т.е. не имеющих заранее известных алгоритмов решения) задач, связанных с познанием жизнедеятельности естественных и рукотворных процессов в любых явлениях мироздания - метод аксиоматического моделирования Кондратенко, эффективность которого достигается путём корректной постановки задачи и её решения чисто формальным методом. Корректность постановки задачи означает, прежде всего, признание несостоятельности всех гипотетических (не подтверждённых результатами натурного экспериментирования с предметом познания) теорий. Это требование, в частности, и к математическому инструментарию, используемому для решения задач познания, выявило парадоксы в основаниях математики, рассмотрению которых посвящена статья.

В настоящее время в естественных и прикладных науках в большинстве публикаций, т.е. более $90 \%$, связанных с построением формальных теорий по этим наукам, доказательство теорем осуществляется:

во-первых, содержательным способом, что противоречит настоятельному требованию философов науки использовать исключительно формальное доказательство, которое является критерием оценки корректности и достоверности доказательства; во-вторых, при содержательном доказательстве в 95\% случаев используется исключительно стандартный перечень тавтологий, который по определению некорректен для целей доказательства теорем о явлениях и процессах мироздания на основе исключительно истинных аксиом, полученных в результате натурного экспериментирования с этими явлениями и процессами. Рассмотрен парадокс при классическом подходе к доказательству теорем, состоящий в непригодности общепринятых стереотипных тавтологий классической математики для доказательства теорем.

Ключевые слова: аксиоматическое моделирование, искусственный интеллект, математическая логика, мышление, формализация. 